\title{
HADITS INFORMATION ABOUT HELPING (COMPLETING) WITH SOMETHING HAPPENED IN THE SOCIETY
}

\author{
Jagat Rayana \\ Pascasarjana UIN Sunan Gunung Djati Bandung \\ Email : rayana1801@gmail.com
}

\begin{abstract}
Today, begging and begging for something that is considered normal is mainly used as a livelihood to meet their needs. This phenomenon continues to develop and has tools that can support its development. This study aims to look at the hadiths about begging and see the implications on social order, with content analysis methods and qualitative data type takhrij methods, namely data relating to authenticity, blasphemy, content and implications of Hadith begging. The main source of data is the books of the Hadith al-Mashhadi al-Ashliyah assisted with supporting data sources that produce the Hadith about begging, namely marfu 'Qauli haqiqi due to the words of Rasulallah SAW and including the Hadith ahad Mashhur because the raw is four at the beginning of thabaqah and subsequently accompanied by several narrators. The hadith asks for clear whereabouts and as a strict rebuke to all creatures of Allah SWT to avoid begging and encourage hard work and earn a living that is lawful to meet all their needs.
\end{abstract}

Keywords: Hadith, Begging, Society

\section{INTRODUCTION}

Begging or begging when viewed in Arabic, then taken from the word (سأل) which means to ask, which means people who often ask (beggars), and (فقل سول) also called the requester (Rohman, 2016). ask for help, charity, donations, both individuals or institutions. Begging is synonymous with worn clothes that display improvised, the thing that encourages a person to beg is because it is easy and fast to get results, simply by reaching out to people to provide assistance or donations (Daulay, 2017; Suhendi, Ramdhani, \& Irwansyah, 2018).

The problem of poverty is a real thing in human life and is still homework for the whole world especially the Indonesian people (Saleh, Riyanto, \& Mustaqim, 2014), in people's lives poverty is a social problem that can affect all aspects of human life and even the possibility of actions that occur contrary to social and religious norms (Safitri, 2018).

Rasulullah SAW recommends working and trying and eating from the results of his sweat (HR. Bukhari) Shahih Bukhari, Juz 3, p. 112. In this Hadith Rasulullah SAW recommends working and trying because in Islam it is mandatory, then every Muslim is required to work and try to prosper this life. Also, if it contains a suggestion to maintain self-respect and avoid the act of begging because Islam as a noble religion has ordered not to do abject work.

This has been exemplified by the Prophets and Apostles as they support themselves and their families by working hard as the US Dawud was able to make armour, the US Zakaria US as a wood seller, the intelligence and honesty of the Prophet Muhammad as a merchant, and it was done by his own hands. Like, the words of Rasulullah SAW (HR. Muslim, Muslim Saheeh, Juz 8, p. 142, no. 2379)

Asking is permissible and permissible, but it can be interpreted here if someone in a state of not having anything at that time, in other words, namely in a state of urgency or very forced. So the act of

* Copyright (c) 2019 Jagat Rayana

This work is licensed under a $\underline{\text { Creative Commons Attribution-ShareAlike 4.0 International License. }}$

Received: 10 November 2018; Revised: 25 December 2018; Accepted: 30 December 2018 
begging is said to be despicable if the work is in a state completely sufficient so that it will humble itself both in the eyes of humans and in the sight of Allah SWT in the hereafter (Rayana, 2016).

Man in his life is free from trials and exams because trials and exams are Sunnatullah, man will be tested in all the good things that he likes like health, wealth or what he does not enjoy in the form of poverty, poverty and so on. Allah Almighty says in the Qur'an:

"And surely We will give you a trial, with a little fear, hunger, lack of wealth, soul and fruit. and bring good news to those who are patient. (that is) those who, when afflicted, says: "Inna lillaahi wa innaa ilaihi raaji'uun (Qs al-Baqarah (2) verse: 155-156)."

This is certainly closely related to one's mentality, the culture of begging is a lazy mentality that expects something in an instant way (Hardiyantina \& Sukardi, 2016), does not want to work hard and always expects from others. How would it be if this culture expanded among them, of course, this should be a serious concern for us together, not only the government, not only social services but all Indonesian people have the responsibility to solve this problem. In this day and age, begging or begging is considered a normal thing and even some of them make it a livelihood to meet their needs even to collect wealth from the results of begging.

Beggars or begging is a disease in society or commonly referred to as social pathology. In the 19th and early 20th centuries, sociologists defined social pathology, which is all behaviour that is contrary to norms of goodness, local stability, patterns of simplicity, morals, property rights, solidarity, family, living in harmony, discipline, kindness, and formal law.

What is meant by social problems are all forms of behaviour that violate community customs (and those customs are needed to ensure the welfare of living together)? Social pathology can also be defined, namely the social situation which is considered by most members of the community as disturbing, undesirable, danger and harm to many people (Sukardi, 2017).

From the above phenomena, many factors encourage a person to become a beggar including:

1. Factors of helplessness and poverty experienced by people who are experiencing economic hardship to meet the daily needs of their families. Because indeed they do not have a fixed salary, routine benefits or other sources of life. And they don't have special skills that they can use to make money.

2. Factors of economic difficulties that are being faced by people who have experienced substantial property losses, such as entrepreneurs who have been hit by bankruptcy or traders who have gone bankrupt.

3. Factors that come suddenly such as having to pay a lot of debt to various parties without being able to pay it.

4. The factor of economic hardship that is not balanced between the daily income earned and the amount of income that must be spent to meet the needs of a large number of family members.

As we have known, the beggar tackling by using administrative patterns alone without looking at and researching the factors that generate or encourage and cause the problem to become more effective, so that it can be effectively dealt with requires research and observing appropriate solutions to the solution (Noviariza \& Sugandi, 2018).

This is evidenced by the increasing number of beggars and increasing needs and high unemployment that has an impact on economic difficulties. Therefore, an in-depth research is needed so that the response to the problem is right on target so that it is easy to overcome it. then it is necessary to further study and verify the Hadith regarding the prohibition of begging. 


\section{RESEARCH METHODS}

The method used in this study is the library research, content analysis and the method of takhrij. The library research method (library research) is carried out by collecting data contained in literature books, magazines, newspapers, seminar results and other materials related to the problem taken (Ratna, 2010). This research was conducted by examining books and writings relating to the Hadith about Begging.

The content analysis method is a research method that utilizes a set of procedures to draw authentic conclusions from a document or message that is carried out objectively and systematically. The method of takhrij is a special method used in examining the degree of quality of the Hadith. The method of takhrij means the mention of the Hadith with each of its sanad in the Hadith sourcebook and explains its dignity according to the needs (Maulana, 2016). Data was collected using documentary studies (documentary). That is a data collection technique by collecting and analyzing documents both written, image and electronic. While the documents that have been obtained are then analyzed (analyzed), compared and integrated (synthesis) to form a systematic study.

\section{RESULTS AND DISCUSSION}

\section{Tafhim and Tathbiq problems}

\section{The Mushrooming of Begging Culture (Begging)}

the law of begging is haram except that which is permissible as explained in the Hadith of the Prophet SAW Narrated from the Friends of Qabishah ibn Mukhariq al-Hilali Radhiyallahu 'anhu, he said: Rasulullah Sallallahu' Alayhi wa sallam said:

"O Qabiishah! Surely begging is not lawful, except for one of the three people: (1) someone who bears the debt of another person, he may beg until he repays it, then stops, (2) someone who has been struck by a disaster spends his wealth, he may beg until he gets the back of life, and (3) someone who is afflicted by the misery of a life so that there are three sensible people from his people saying, "The Fulan has been afflicted by the misery of life, he may beg for to get back of life Requesting other than those three things, O Qabishah! It is haram, and the person who eats it is eating haram (Saheeh Muslim, No. 1044; Abu Daud no. 1640)."

But in reality, what happens in the community asking for (begging) is considered a normal thing and even used as a livelihood, this phenomenon continues to grow and has a variety of patterns and devices that can support its development, and this is all homework for all layers that must be overcome immediately.

Everyone agreed that the parties responsible for the problem of the phenomenon of begging had done a good job. They had made positive efforts in facing and overcoming the problem optimally. So that the problem of giving can go on in a form that is in line with the flow of progress that demands its existence in all fields of life. The obligation to work hard and correct any shortcomings of what we do so that in the future we can get better results. The task of dealing with beggars is not only on the shoulders of the government but it must be borne by all components of society according to the portion of their respective responsibilities. 


\section{Constraints in countermeasures}

In dealing with beggars, there are no doubt a lot of obstacles including the following:

1. The scope and phenomena of sudden begging.

2. Like seasonal beggars, such as during Ramadan, big events / celebrations, and so on

3. Limited human resource capacity, which is not balanced with a large number of beggars and other problems that must be faced.

4. Depletion of the energy of social institutions to arrest beggars, this kind of work is very heavy if there is no assistance or support from various facilities and infrastructure such as manpower, adequate allocation of funds, patrol cars to be used as transporters and so forth.

5. There is no concrete data about the number of poor people who are forced to beg and the number of poor people who are hesitant to beg because of the consideration of religious values, social norms and traditions.

6. The ineffectiveness of administrative efforts whose role is only focused on the matter of the prohibition without any problem solution.

7. In dealing with beggars, officers face obstacles while working in the field, when they want to arrest beggars, due to the lack of awareness of some members of the community and their understanding of the objectives of the arrest attempt, some publics openly obstruct arrest.

8. Some community members feel sorry for those who ask because they cannot bear to see the appearance of a beggar without proving the truth.

Muslim society is responsible for the lost individuals, one is obliged to recognize poor people, starting from relatives and neighbours around him to the level of poor people in his country. when giving help, one must examine the circumstances of the people who need it.

Islam encourages the community to provide compulsory assistance to the weak of the poor who need it. That is through zakat in the form of money or crops, livestock and others. Likewise, they must issue zakat fitri and sacrifice on the feast, Allah SWT said:

"Cleanse and purify them and pray for them. Verily, your prayers (become) peace of mind for them. and Allah is heard again, All-knowing (Qs al-Taubah (9) verse: 103). "

Islam also recommends investing in kindness by giving as much Sadaqah as possible, as well as helping the weak and the poor who are in dire need of help Allah says:

"O you who believe, spend (in the way of Allah) a portion of the fortune that we have given you before the day comes that day no more buying and no more sharia. and disbelievers That are the wrongdoers. (Surat al-Baqarah (2) verse: 254)."

The solution to realize the desired results in overcoming the phenomenon of begging that is rife in the community must be research or analyze this problem. For fake beggars who are caught begging again, sanctions must be given to discourage them and not repeat them. However, there must be officers who conduct surveillance and arrest to facilitate efforts to overcome them by the degree of the problem and its scope. For beggars from groups of poor people consisting of children and parents who are caught, it is necessary to get the services of social foundations and include them because they need and do not have families to care for them. For beggars from other poor groups can find jobs for those who are by their abilities and skills and expertise (Jawas, 2018). Besides that, it is also necessary to provide guidance and their education especially moral education so that they can know and understand begging that is allowed and which is not allowed in religion and explain that the act is a despicable and despicable act which is forbidden by religion. 
IJIK, Vol.9 No. 1: 35-40

Hadits Information About Helping (Completing) With Something Happened In The Society

Jagat Rayana

\section{Implications of the Hadith About Requesting (Begging) with Amaliyah that occurs in the Community}

Since ancient times until now the practice of begging is a real phenomenon amid the community and not endless in tackling it even the practice of begging has become a profession to meet the necessities of life. In today's time's begging (begging) is considered a normal thing and even used as a livelihood, the phenomenon continues to grow and has a variety of patterns and devices that can support its development. Therefore, the Hadith prohibits begging (begging) that the author has discussed is a clear and real hujjah regarding the prohibition and contempt of the practice of begging without Haq or out of the provisions that have been explained by the Shari'ah as has been confirmed in the words of the Prophet SAW in the Hadith of Qabishah.

From the Hadith above it is clear beyond the stipulations that he has mentioned that the case of the practice of begging is behaviour that is not justified in shari'ah. One thing that must be known together that begging is an insult that should be avoided. The obligation for a Muslim and generally for all humans is always trying to find the gift of God and the permissible fortune to meet their needs. Because the best food is produced by his efforts it is the sunnah of the Prophets and Apostles as explained in the words of the Prophet SAW:

"From Mikdam Radiyallahu' anhu Rasulallah SAW said: It is not a person who eats a food that is better than the work of his own hands and indeed the Prophet Daud 'Alaihi greetings eat from the results of his handwork (Rayana, 2016)."

In the Hadith about the prohibition of asking (begging) to give a very big lesson as a solution in overcoming the phenomenon of begging practices that are mushrooming in the community, so it is expected for a Muslim who obeys Allah SWT and his Apostles should pay attention and take wisdom from the prohibition of the Hadith. begging is a joint responsibility of all people if understood objectively the phenomenon is expected to encourage to be fair and wise as a form of accountability before God and his Apostles and the community. However, beggars are a group that has the rights that must be fulfilled to realize social solidarity, especially the authorities who are obliged to resolve their problems completely. If it does not have the ability or opportunity to overcome the problem, it can at least inspire those who are able and have the opportunity to overcome it by giving the rights of the weak.

\section{CONCLUSION}

The phenomenon that occurs in society will be the rise of fake beggars who are troubling the community with a variety of different patterns and ways to attract sympathy so that people sympathize with it, with. The existence of this Hadith is a strong warning against them so they are reluctant to practice, indirectly this Hadith inspires those who have the wealth to give away some of their wealth to those who are unable

\section{REFERENCES}

Daulay, S. (2017). Konsep Hadis Tentang Meminta-Minta. At-Tahdis: Journal Of Hadith Studies, 1(2). Hardiyantina, R., \& Sukardi, S. (2016). Studi Etnografi Perilaku Pengemis Masyarakat Desa Pragaan Daya Kabupaten Sumenep. Publisia: Jurnal Ilmu Administrasi Publik, 1(1).

Jawas, Y. Bin A. Q. (2018). Hukum Lagu, Musik, Dan Nasyid. Bogor: Pustaka At-Taqwa.

Maulana, L. (2016). Periodesasi Perkembangan Studi Hadits (Dari Tradisi Lisan/Tulisan Hingga Berbasis Digital). Esensia: Jurnal Ilmu-Ilmu Ushuluddin, 17(1), 111-123. 
IJIK, Vol.9 No. 1: 35-40

Hadits Information About Helping (Completing) With Something Happened In The Society Jagat Rayana

Noviariza, I., \& Sugandi, S. W. W. (2018). Upaya Satuan Polisi Pamong Praja Kota Samarinda Dalam Menanggulangi Gelandangan Dan Pengemis Melalui Komunikasi Persuasif Di Kota Samarinda. Ejournal Ilmu Komunikasi, 6(3).

Ratna, N. K. (2010). Metodologi Penelitian: Kajian Budaya Dan Ilmu Sosial Humaniora Pada Umumnya. Yogyakarta: Pustaka Pelajar.

Rayana, J. (2016). Arah Dan Kritik Dengan Metode Takhrij Hadits Tentang Meminta-Minta. I'tibar, 3(6), $15-29$.

Rohman, A. (2016). Pengemis Dalam Ekonomi Islam. Dinar: Jurnal Ekonomi Dan Keuangan Islam, 3(2).

Safitri, J. (2018). Implementasi Konsep Zakat Dalam Al-Qur'an Sebagai Upaya Mengentaskan Kemiskinan Di Indonesia. At-Tasyri', 1-15.

Saleh, K., Riyanto, R., \& Mustaqim, M. (2014). Tradisi Mengemis: Pergulatan Antara Ekonomi Dan Agama: Studi Perilaku Mengemis Masyarakat Di Demak. Jurnal Penelitian, 8(1), 23-44.

Suhendi, H. Y., Ramdhani, M. A., \& Irwansyah, F. S. (2018). Verification Concept Of Assesment For Physics Education Student Learning Outcome. International Journal Of Engineering \& Technology (Uea), $7(3.21), 321-325$.

Sukardi, R. (2017). Pendidikan Nilai; Mengatasi Degradasi Moral Keluarga. Prosiding Seminar Nasional Pendidikan Fkip, 1(2). 